\title{
Enzymatic changes in orchard workers with occupational exposure to pesticides
}

\author{
Svetlana Cekovska ${ }^{1}$, Sasho Stoleski ${ }^{2}$, Violeta Soleva ${ }^{3}$, \\ Katerina Tosheska-Trajkovska ${ }^{1}$, Danica Labudovik ${ }^{1}$, Jasna Bogdanska ${ }^{1}$, \\ Julijana Brezovska-Kavrakova ${ }^{1}$, Irena Kostovska ${ }^{1}$, Biljana Bauer ${ }^{4}$, Sonja Topuzovska ${ }^{1}$ \\ ${ }^{1}$ Institute of Medical and Experimental biochemistry, Faculty of Medicine, \\ Ss. Cyril and Methodius University, Str. 50 Divizija No. 6, 1000 Skopje, R. Macedonia \\ ${ }^{2}$ Institute of Occupational Health of R. Macedonia, WHO CC, \\ Str. Vtora Makedonska Brigada 43, 1000 Skopje, R. Macedonia \\ ${ }^{3}$ Private health institution Avicena laboratory, Boulevard 8-mi Septemvri 12, \\ 1000 Skopje, R. Macedonia \\ ${ }^{4}$ Institute of Pharmacognosy, Faculty of Pharmacy, Ss. Cyril and Methodius University, \\ Str. Majka Tereza 47, 1000 Skopje, R. Macedonia
}

Received: November 2018; Accepted: January 2019

\begin{abstract}
Organophosphates (OP) and carbamates, frequently used pesticides, can cause a variety of adverse health effects, ranging from simple irritation of the skin and eyes to more severe effects. The aim of this study was to evaluate the association between chronic occupational pesticide exposure and changes in serum activities of alanine aminotransferase (ALT), aspartate aminotransferase (AST), gamma glutamyl transferase (GGT), alkaline phosphatase (ALP), acetylcholinesterase (AChE) and creatine phosphokinase (CPK) in orchard workers. In the study, 47 peach orchard workers were included, at the age from 19 to 60 years, with monthly exposure to pesticides from 5 to 20 days and 1 to 35 working years. The control group consisted of 40 healthy age-matched men, without exposure to pesticides. All orchard workers kept to safety precautions. $68 \%$ of workers reported some physical signs and symptoms. A significantly decreased AChE activity was detected in $10.6 \%$ of orchard workers and increased CPK activity in $40.4 \%$. Very weak negative correlation was detected between AChE and ALP activities $(r=-0.34, p=0.001)$ and between AChE and CPK activities $(r=-0.25$, p = 0.02). No correlation was found between the serum AChE and day of monthly exposure, as well as years of exposure. The results have shown that orchard workers with decreased AChE activity and increased CPK activity should be monitored as workers with an increased risk for severe pesticide poisoning. These findings suggest that chronic occupational exposure to pesticides elicit mild toxic effects, as well as biochemical changes of unknown long-term consequences.
\end{abstract}

Keywords: Toxic effects; Carbamates pesticide, Organophosphate pesticide, Serum enzymes, Orchard workers, Occupational exposure

\section{Introduction}

Organophospates (OP) and carbamates, frequently used pesticides in the agriculture and in the household gardens, can cause a variety of adverse health effects, ranging from simple irritation of the skin and eyes to more severe effects (Garcia-Garcia et al., 2015). They can be efficiently absorbed by inhalation, ingestion and skin penetration (Chen et al., 2012). The primary toxicity from

\footnotetext{
*svece66@gmail.com
} 
these compounds derives from excessive stimulation of muscarinic and nicotinic cholinergic receptors by the accumulated acethylcholine in the central and autonomic nervous systems as well as at skeletal neuromuscular junctions (Clark et al., 2006), due to decreased Acetylcholinesterase activity (AChE). Furthermore, OP increase reactive oxygen species level which results in oxidative stress and contributes to cell membrane lipid peroxidation, DNA damage and cell death (Milić et al., 2018; Szatkowska et al., 2012; Uzunkhisarcikli et al., 2011).

Acetylcholinesterase is an enzyme that catalyse the hydrolysis of acetylcholine to choline and acetic acid. The enzyme is present throughout the body, but is particularly important at the myoneural junction, where the nerve fibers terminate. Acetylcholine is released when a nerve impulse reaches neuromuscular junction. It diffuses across the synaptic cleft and binds to cholinreceptors in the muscle fibers, causing them to contract. Cholinesterase splits acetylcholine into its components, thus stopping stimulation of the muscle fibers. The end products of the metabolism of acetylcholine are taken up by nerve fibers and resynthesized into acetylcholine. Abnormal AChE may occur due to a) various physiological and pathological conditions, b) genetic factors or c) interaction with drugs (neostigmine, physostigmine and pyridostigmine) and cholinesterase inhibitors, such as organophosphorus and carbamate pesticides (Jokanović et al., 1997).

Pesticide poisoning is usually confirmed by detection of cholinesterase inhibition (Jokanović et al., 1997; McQueen, 1995; Trundle et al., 1988). But, also there is substantial evidence for changes in the activity of some other enzymes in the serum, that correlate with the severity of poisoning (Awad et al., 2014; Bhattacharyya et al., 2011; Hernández et al., 2006).

Human cholinesterase exists in two formsacethylcholinesterase located in tissue microsomes and erythrocytes and serum cholinesterase found in serum or plasma. The two enzymes display marked difference in structure, substrate specificity, biological function and origin (Trundle et al., 1988). Laboratory evidence of OP and carbamates poisoning is usually confirmed by measuring the decrease in the plasma butyrylcholinesterase (BChE) and erythrocyte cholinesterase (EChE) activities. However, because of wide inter-individual variability, significant depression of the EChE activity may occur but still fall within the "normal" range (Tanen et al., 2007). Also, estimation of either EChE or BChE levels is costly and not routinely performed in most laboratories. In practice, serum AChE activity is measured. Clinical applications are primarily centered on subnormal levels of enzyme activity. Changes in enzyme activity should be related to baseline levels because there is wide individual variation. One baseline levels have been established, serum AChE activity becomes a sensitive indicator of pesticide intoxication and hepatic biosynthetic capacity (Jokanović et al., 1997; Trundle et al., 1988).

Exposure to pesticides both occupationally and environmentally causes a range of human health problems. It is estimated that nearly 10000 deaths occurred annually, due to use of pesticides worldwide, with about three-fourth of these occurring in developing countries (Horrigan et al., 2002). The potential risks for agriculture workers occupationally exposed to pesticides are greater than the risks to someone in the general population exposed only to traces of pesticides in food or water (Amer, 2002).

The activities of aminotransferases alanine amonotransferase (ALT) and aspartate aminotransferase (AST), as well as gamma glutamyl transferase (GGT) and alkaline phosphatase (ALP) are the most frequently used as specific indicators for liver function and hepatocellular damage (Araoud et al., 2012; Awad et al., 2014). Several studies have shown that there is a highly significant correlation between serum creatine phosphokinase (CPK) activity and the severity of acute organophosphorus poisoning and recommended $\mathrm{CPK}$ as an alternative biomarker in diagnosis and prognostication of acute OP poisoning (Dayanand et al., 2012; Nermeen et al., 2013). Enzyme activities are among the biomarkers that may be used to detect the effects of pesticides before adverse clinical health effects occur (Hernández et al., 2006). In many studies the evaluation of toxic effects of some OP pesticides on serum enzyme activities was done on animals (Burke et al., 2017; Kackar et al., 1999; Kopjar et al., 2018; Sukhdeep et al., 2004).

In this study activities of several serum enzymes such as: ALT, AST, ALP, CPK, GGT and AChE were examined. Also, the examination of correlation between AChE activity and activities of other above mentioned examined enzymes was done.

The aim of the study was to evaluate the association between chronic occupational pesticide exposure and changes in the several enzyme activities in serum, as well as to evaluate symptoms and physical examination signs, in orchard workers, working on peach plantation.

\section{Material and methods}

\section{Subjects}

The study included 47 peach orchard male workers from Strumica region in the Republic of Macedonia, employed in a medium-sized enterprise, aged from 19 to 60 years, with monthly exposure to pesticides from 5 to 20 days on an open field having 1 to 35 working years of exposure. Control group consisted of 40 healthy agematched men, without occupational exposure to pesticides.

Workers were informed about the names and potential health consequences of pesticides used; they 
were supplied with protective equipment as pesticide handlers (farm workers who mix, load, or apply pesticides); and provided with pesticide safety training required to enter fields that recently have been or will be treated with pesticides. The training also promotes occupational behaviors to reduce pesticide exposures such as wearing clothing that protects the skin (e.g., a longsleeved shirt, pants, closed-toe shoes, and a hat); wearing clean work clothes; handwashing with soap; eating outside of the field; washing fruits and vegetables taken from the fields before eating them; and showering or bathing after the field work is finished. All orchard workers kept to safety precautions, including wearing safety clothes, use of special mask and gloves and special eye glasses.

All workers were asked to fulfill the questionnaire that included question related to existing symptoms and physical signs (such as irritations of skin and eyes, headache, fatigue, muscle twitch (fasciculation), dry cough, sweating, vomiting, diarrhea, abdominal pain, increase secretion of saliva), history of any disease or conditions, type of pesticides used, duration of monthly exposition and duration of working years with chronic pesticide exposure. This specially designed questionnaire was adopted from Guidance material: Baseline health monitoring before starting work in an organophosphate pesticides process (Safe Work Australia 2008). The questionnaire was designed to record the personal and occupational information along with pesticide exposure and health status of the pesticide sprayers. Each pesticide sprayer was interviewed based on questionnaire about demography, smoking habit, exposure period of pesticide spraying in respect of years, type of pesticides used, methods of spraying, work practices during spraying the pesticides such as whether they handle the pesticides with bare hands or measuring cup, whether they wear any protective equipment, whether they eat anything while spraying, whether they take bath after spraying etc., and health information through patient history and clinical examination, including self-reported toxicity symptoms associated with pesticide use.

Orchard workers included in this study were exposed to methomyl (carbamate insecticide), mancozeb (fungicide, based on manganese and zink) and chlorpyrifos-cipermetrin (organophosphate insecticide). The pesticides were prepared in the way and in concentrations recommended by manufacturers and used for spaying only on open peach plantation.

As pesticides have been linked with various chronic diseases, workers presenting neurological disorders, liver dysfunction, diabetes or any other chronic illnesses were excluded from the study.

This work was approved by the Ethical Committee of the Medical Faculty-Skopje. Informed consent was obtained from the parents.

\section{Experimental setup}

The whole vein blood samples were collected by venipuncture using tubes with ethylenediamine-tetraacetic acid potassium salt, from examined peach workers at the beginning of June. Samples were stored in a portable refrigerator and taken to the laboratory. Upon arrival at the laboratory, serum was separated by centrifugation and analyzed the same day for above mentioned enzyme activities.

Serum activities of alanine aminotransferase (ALT), aspartate aminotransferase (AST), gamma glutamyl transferase (GGT), alkaline phosphatase (ALP), acetylcholine esterase (AChE) and creatine phosphokinase (CPK) were analyzed on an automated biochemical analyzer ChemWell Awareness Technologies, INC, by standard spectrophotometric assays (Burtis, et al., 1994; Burtis, et al., 1999; Panteghini, et al., 2006; Szasz, 1976; Tietz, et al.,1995; Vassault, et al., 1999).

\section{Statistical analysis}

The collected data were organized, tabulated and analyzed using SPSS version 17 software. Categorical data were presented as numbers and percentages while quantitative data were expressed as mean and standard deviation. Student t-test, Difference test and Pearson correlation coefficient (r) were used as tests of significance. The accepted level of significance in this work was stated at $0.05 \quad(\mathrm{p}<0.05$ was considered significant, CI 95\%).

\section{Results and discussion}

\section{Demographic results}

The demographic characteristics of orchard workers exposed to pesticides are summarized in Table 1.

Out of 87 peach orchard workers enrolled in the study, all (100\%) were males, aged from 19 to 60 years, $47(54 \%)$ were occupationally exposed to pesticides and $40(\%)$ were not exposed (control group). In the exposed group $28(59.6 \%)$ were worker's sprayers, $15(31.9 \%)$ were tractor drivers and $4(8.5 \%)$ agronomists. The percentage difference between sprayers and other (tractor drivers plus agronomists) is significant, $\mathrm{p}<0.05$ (Difference test, $\mathrm{p}=0.00$ ). From this reason, results were interpreted for whole group. Regarding to the years of exposition, $34 \%$ of workers were exposed more than 10 years, $29.8 \%$ from one to five years, $25.6 \%$ were exposed from 6 to 10 years and $10.6 \%$ less than one year. The percentage difference is statistically significant between exposed over 10 years and exposed to five years versus exposed under one year, $\mathrm{p}<0.05$ (Difference test, $\mathrm{p}=$ 
Table 1. Demographic characteristics of orchard workers exposed to pesticides

\begin{tabular}{lcc}
\hline \hline Profession & $\mathrm{N}$ & $\%$ \\
\hline agronomist & 4 & 8.5 \\
worker & 28 & 59.6 \\
tractor driver & 15 & 31.9 \\
\hline Exposed/years & & 34.0 \\
\hline$>10$ & 16 & 10.6 \\
$<1$ & 5 & 29.8 \\
$1-5$ & 14 & 25.6 \\
$6-10$ & 12 & \\
\hline Exposure during the day/hours & & 21.3 \\
\hline$<6$ & 10 & 40.4 \\
$<2$ & 19 & 38.3 \\
$2-6$ & 18 & \\
\hline Exposure per month (days) & & 59.6 \\
\hline $2-10$ & 28 & 27.7 \\
$11-20$ & 13 & 12.7 \\
$>20$ & 6 & \\
\hline Symptoms & & 31.9 \\
\hline no & 15 & 68.1 \\
\hline
\end{tabular}

0.0064, $\mathrm{p}=0.0204)$. Out of all exposed workers, $40.4 \%$ were with average daily exposition under two hours, $38.3 \%$ from two to six hours and $21.3 \%$ more than six hours. Regarding the exposition days per month, $59.6 \%$ of examinees were exposed from 2 to 10 days per month, $27.7 \%$ from $11-20$ days per month and $12.7 \%$ on average 20 days per month. In $68.1 \%$ of exposed orchard worker's symptoms and physical signs were detected versus $31.9 \%$ without symptoms and signs. The percentage difference was statistically significant, $\mathrm{p}<0.05$ (Difference test, $\mathrm{p}=$ 0.0004). The demographic characteristics of exposed to pesticides examinees are summarized in Table 1.

\section{Clinical results}

From all peach orchard workers included in the study, $68 \%$ reported some symptoms such as: irritations of skin and eyes, headache, fatigue, muscle contractions, dry cought, sweating and abdominal pain. Most of the workers manifested skin rash and redness $(19=40.4 \%)$, followed by headache $(9=19.2 \%)$, sweating $(7=14.9 \%)$, dry cough $(6=12.8 \%)$, eye itchiness $(6=12.8 \%)$, muscle twitch $(4=8.5 \%)$, vomiting $(3=6.4 \%)$, salivation $(2=$ $4.3 \%)$, abdominal pain $(2=4.3 \%)$ and fatigue $(2=4.3 \%)$. The results from the evaluation of symptoms and physical signs in orchard workers are presented in Fig. 1.

The results for average serum enzyme activities in peach orchard workers exposed to pesticides and in the control group of non-exposed healthy men are shown in Table 2.

The average level for ALT activity in exposed group of examinees was $26.88 \mathrm{U} / \mathrm{L}$ and $25.06 \mathrm{U} / \mathrm{L}$ in the control group (within reference interval $0.0-40.0 \mathrm{U} / \mathrm{L}$ for both groups). The difference is not statistically significant, $\mathrm{p}>$
0.05. Out of all peach orchard workers exposed to pesticides, $12.8 \%$ had increased values for ALT higher than upper limit of reference interval versus $0 \%$ in control group.

The average level for AST activity in exposed group of examinees was $25.08 \mathrm{U} / \mathrm{L}$ and $27.05 \mathrm{U} / \mathrm{L}$ in control group (within reference interval 0.0-38.0 U/L for both groups). The difference is not statistically significant, $p$ > 0.05 . Out of all peach orchard workers exposed to pesticides, $10.0 \%$ had values for AST higher than upper limit of reference interval versus $0 \%$ in the control group.

The average level for GGT activity in exposed group of examinees was $33.88 \mathrm{U} / \mathrm{L}$ and $30.54 \mathrm{U} / \mathrm{L}$ in the control group (within reference interval 9.0-61.0 U/L for both groups). The difference is not statistically significant, $p$ > 0.05 . Out of all peach orchard workers exposed to pesticides, $12.8 \%$ had values for GGT higher than upper limit of reference interval versus $0 \%$ in the control group.

The average level for ALP activity in exposed group of examinees were $186.92 \mathrm{U} / \mathrm{L}$ and $99.09 \mathrm{U} / \mathrm{L}$ in control group (within reference interval 64.0-306.0 U/L for both groups). The difference was statistically significant, $\mathrm{p}<$ 0.05 . Out of all peach orchard workers exposed to pesticides, $2.1 \%$ had values for ALP higher than upper limit of reference interval versus $0 \%$ in the control group.

The average activity for AChE activity in exposed group of examinees was 6894.88 U/L (within the reference interval $4200-11200 \mathrm{U} / \mathrm{L}$ ) and $8055.7 \mathrm{U} / \mathrm{L}$ in control group (within reference interval). The difference is statistically significant, $\mathrm{p}<0.05$. Out of all peach orchard workers exposed to pesticides, $10.6 \%$ had values for $\mathrm{AChE}$ lower than low limit of reference interval versus $0 \%$ in the control group.

Maced. pharm. bull., 64 (2) 17 - 26 (2018) 


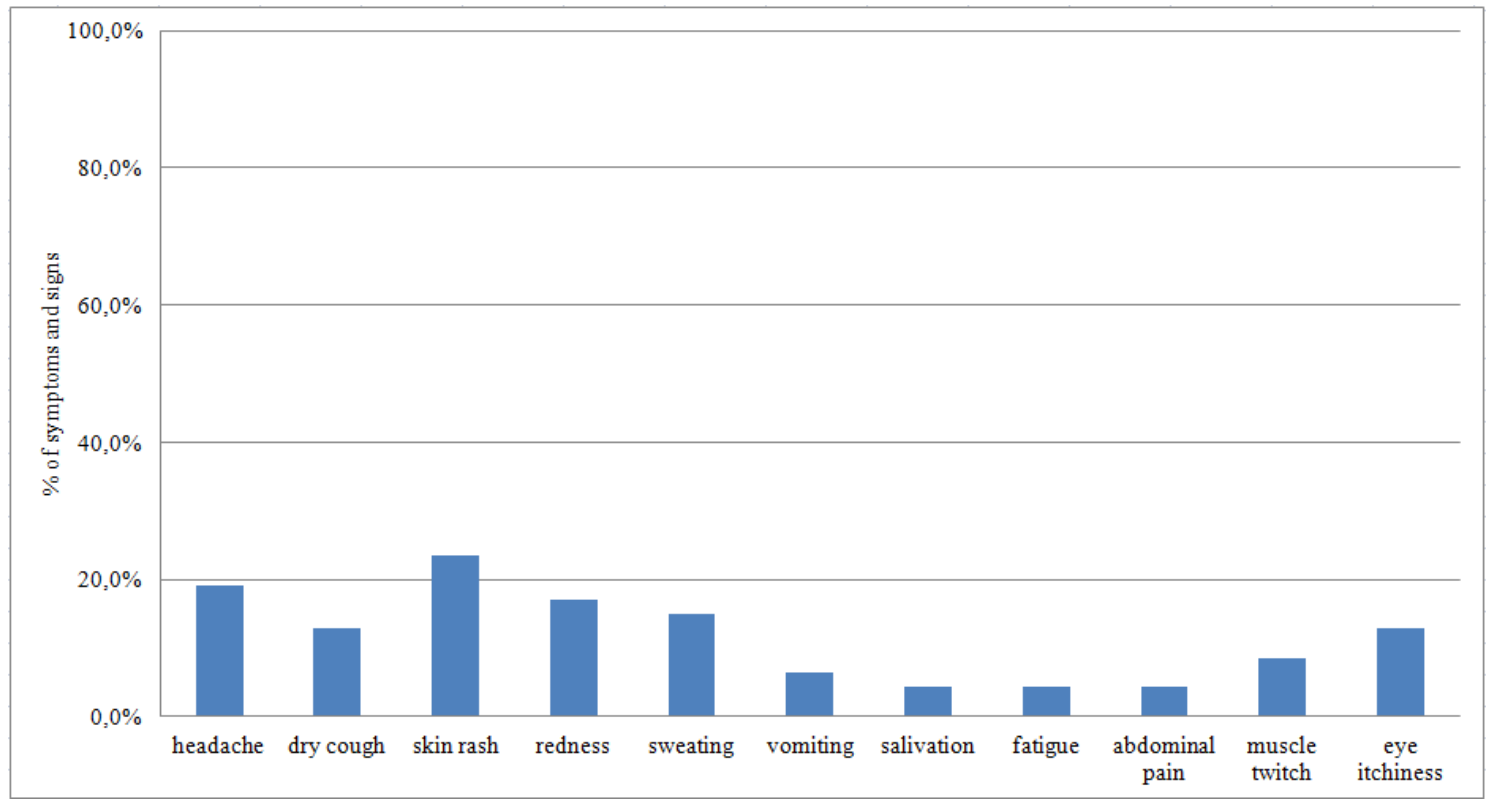

Fig. 1. Bar chart for distribution of the studied orchard workers, according to the characteristic symptoms and sign.

The average level for CPK activity in exposed group of examinees was $218.36 \mathrm{U} / \mathrm{L}$ (higher than upper limit of reference interval 24.0-195.0 U/L) and 115.22 U/L in the control group (within reference interval 24.0-195.0 U/L for both groups). The difference is statistically significant, $\mathrm{p}<0.05$. Out of all peach orchard workers exposed to pesticides, $40.4 \%$ had values for CPK higher than upper limit of reference interval versus $0 \%$ in the control group.

The correlation analysis was made between serum AChE activity and activities of other examined enzymes, as well as between duration of exposition (days of monthly exposure and years of chronic and occupational exposure to pesticides).

The correlation analysis has shown that there is no correlation between the serum AChE levels and days of monthly exposition $(\mathrm{r}=0.098, \mathrm{p}=0.514)$, as well as years of exposure $(\mathrm{r}=-057, \mathrm{p}=0.706)$ in peach orchard workers occupationally exposed to pesticides.
A weak negative correlation $(r=-0.25, p=0.02)$ between values of $\mathrm{AChE}$ and $\mathrm{CPK}$ activities in orchard workers on chronic exposure to pesticides was detected as shown on Fig. 2, as well as a weak negative correlation ( $\mathrm{r}$ $=-0.34, p=0.001$ ) between activities of AChE and ALP as shown on Fig. 3.

In the present study, in $68.1 \%$ of exposed orchard workers reported symptoms and physical signs versus $31.9 \%$ without symptoms and signs. The percentage difference was statistically significant, $\mathrm{p}<0.05$ (Difference test, $\mathrm{p}=0.0004$ ). The results are in agreement with other studies, such as the study of Neupane et al. (2014) and Garcia-Garcia et al. (2015). These studies reported that chronic occupational exposure to pesticides of lower toxicity elicits mild toxic effects, particularly targeting skin and eyes.

Regarding the serum enzyme activities, the results from this study have shown that the average level of

Table 2. Average serum enzyme activities in peach orchard workers exposed to pesticides and in the control group

\begin{tabular}{cccc}
\hline \hline Enzyme & $\begin{array}{c}\text { exposed to pesticides group }(\mathrm{N} \\
=47)\end{array}$ & $\begin{array}{c}\text { control group } \\
(\mathrm{N}=40)\end{array}$ & p value \\
\hline ALT (U/L) & $26.88 \pm 16.75$ & $25.06 \pm 4.24$ & 0.51 \\
AST (U/L) & $25.08 \pm 11.48$ & $27.05 \pm 4.52$ & 0.31 \\
GGT (U/L) & $33.99 \pm 37.75$ & $30.54 \pm 10.66$ & 0.58 \\
ALP (U/L) & $186.92 \pm 57.02$ & $99.09 \pm 34.42$ & $0.00^{*}$ \\
AChE (U/L) & $6894.88 \pm 1855.59$ & $8055.70 \pm 1513.21$ & $0.00^{*}$ \\
CPK (U/L) & $218.36 \pm 185.06$ & $115.22 \pm 31.94$ & $0.00^{*}$ \\
\hline
\end{tabular}

Data are expressed as mean \pm standard deviation

$* \mathrm{p}=0.00$ (statistically significant difference) 


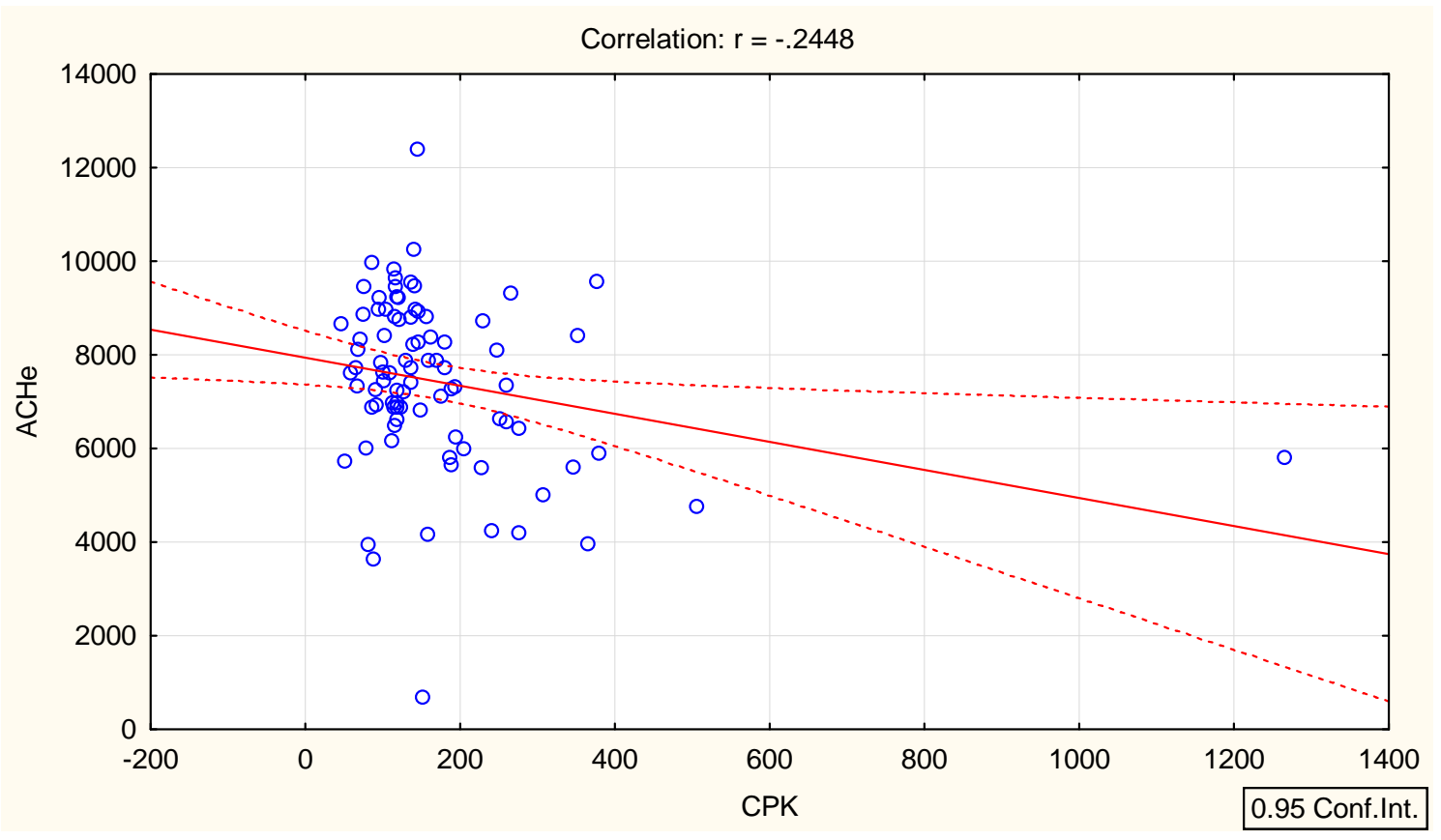

Fig. 2. The correlation between AChE and CPK activities in orchard workers occupationally exposed to pesticides.

serum ALT activity both for exposed to pesticides group and non-exposed control group, were within the reference interval, although in $12.8 \%$ of orchard workers increase in ALT activity above the upper limit of reference interval was detected. Also, the average serum activities of AST in peach orchard workers chronically exposed to pesticides as well as in the control group were within the reference interval and only in $10.0 \%$ of orchard workers AST level was higher than the upper limit of the reference interval. The results from the studies of Hernández et al. (2006) and Awad et al. (2014) revealed significantly increased ALT and AST activities compared with controls, in agricultural workers during a spraying season. In the study of Araoud et al. (2012) in Tunisian agricultural workers exposed to the same pesticides as in the present study, significantly increased serum ALT and AST activities were reported, with significant higher activities compared with that in controls $(p<0.001)$. The difference in the results from above mentioned studies compared with the results in the present study might be due to better protection of the workers from the pesticides toxic effects or the better education for the way of its use. In this study there was no significant difference in GGT activity between workers on peach plantation and the controls and the average GGT activities for both groups were within reference interval. Only in $12.8 \%$ of peach orchard worker's higher activities than the upper limit of reference interval was detected. The results from the study of Aroud et al. (2010) have shown that there is no significant difference for GGT activities between Tunisian agricultural workers exposed to pesticides and controls, but very weak positive correlation was found between the GGT and BChE activity $(r=0.28, p=0.03)$, that is with agreement to the fact that GGT plays an important role in the metabolism of pesticides. Regarding the ALP activity, the results from this study have shown the significantly higher levels of ALP activity in peach orchard workers compared with controls $(\mathrm{p}=0.00)$, and weak negative correlation with serum AChE activity $(r=-0.34, p=$ 0.001). The results from the several studies also have shown increased ALP activity in workers chronically and occupationally exposed to pesticides (Araoud et al., 2010; Araoud et al., 2012; Awad et al., 2014). The present study revealed that the serum AChE activity in workers on peach plantation with occupational exposure to pesticides was significantly decreased $(\mathrm{p}=0.00)$ compared with non-exposed controls. Only $10.6 \%$ of exposed to pesticides peach orchard workers had serum AChE activity lower than low limit of the reference interval. These results are in agreement with the results from the study from Awad et al. (2014), Garcia-Garcia et al. (2015), Cotton et al. (2015) and Lutovac et al. (2017). Lutovac et al. (2017) reported that among workers who are constantly exposed to pesticides, serum $\mathrm{AChE}$ is within the reference interval. Having examined the medical records of these workers, it was noted that, in $\mathrm{t}$ $72 \%$, there was a slight fall of AChE activity, each year. The study of Cotton et al. (2015) revealed that regular monitoring of erythrocyte $\mathrm{AChE}$ and serum $\mathrm{AChE}$ will enable agriculture workers exposed to pesticides to reduce exposure and improve their health and safety practices. In the present study the average level for serum CPK activity in exposed to pesticides workers was higher than upper limit of reference interval and was significantly higher compared with controls $(\mathrm{p}=0.00)$. Out of all peach orchard workers exposed to pesticides, $40.4 \%$ had values 


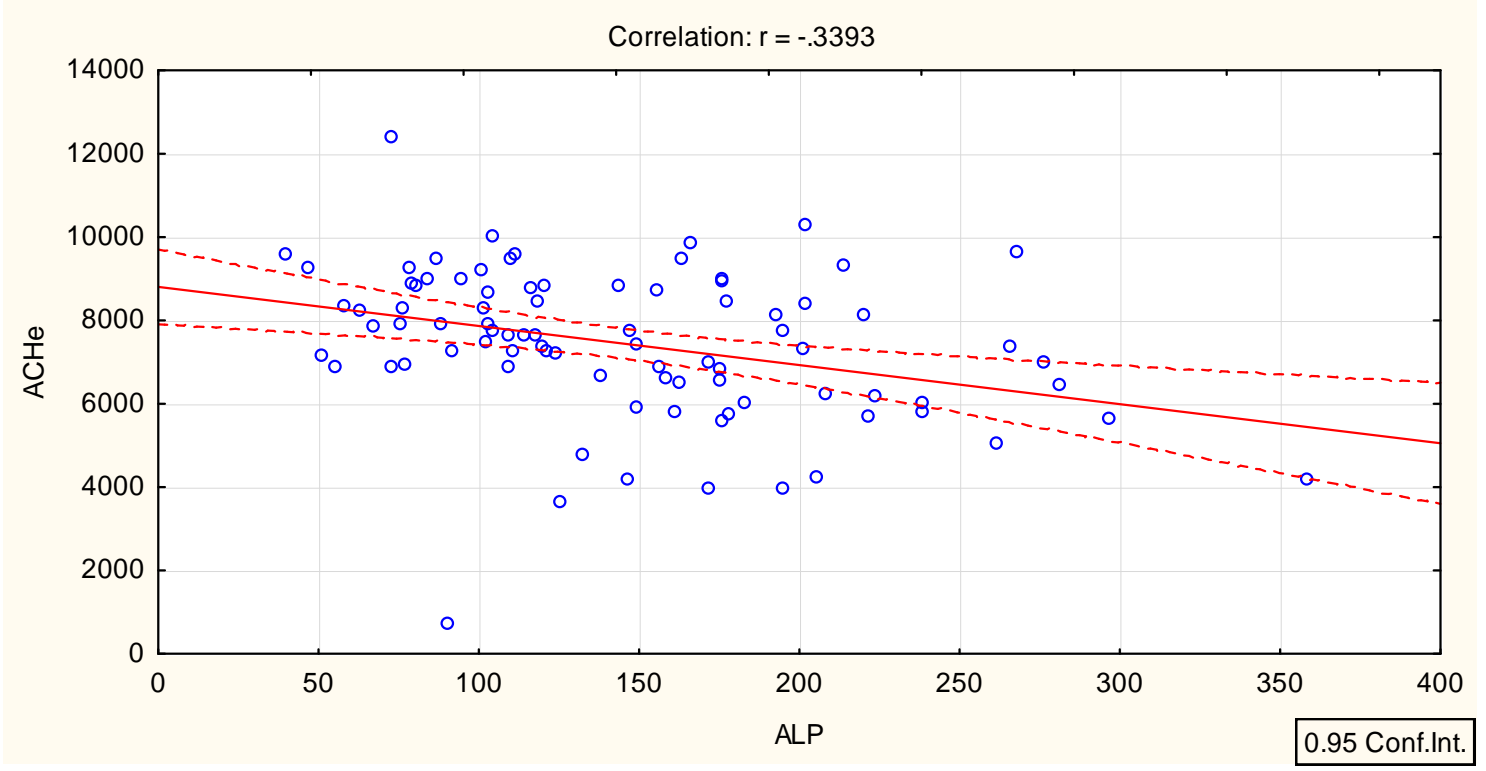

Fig. 3. The correlation between AChE and ALP activities in orchard workers occupationally exposed to pesticides.

for CPK higher than upper limit of reference interval. A weak negative correlation $(r=-0.25, \mathrm{p}=0.02)$ between $\mathrm{AChE}$ and CPK activities in orchard workers on chronic exposition to pesticides, was observed. The results from several studies have confirmed that serum CPK is significantly increased in workers with occupational exposure to pesticides (Araoud et al., 2012; Awad et al., 2014; Bhattacharyya et al., 2011; Dayanad et al., 2012; Hernández et al., 2006; Nermeen et al., 2013). The prospective clinical study by Nermeen et al. (2013) reported that there was a highly significant correlation between initial serum CPK levels and severity of acute OP poisoning. This study recommends serum CPK as an alternative biomarker for acute OP poisoning.

The results from this study have shown that there is no correlation between the serum AChE levels and days of monthly exposition $(\mathrm{r}=0.098, \mathrm{p}=0.514)$, as well as years of chronic and occupational exposure to pesticides $(\mathrm{r}=-057, \mathrm{p}=0.706)$ in examined peach orchard workers. These results are probably due to small number of peach orchard workers occupationally exposed to pesticides included in the study. Trundle et al. (1988) revealed that changes in enzyme activities should be related to baseline levels because there is wide individual variation as well as methodological variation. Once baseline levels have been established, cholinesterase activity becomes a sensitive indicator of pesticide intoxication and hepatic biosynthetic capacity. The study of Lutovac et al. (2015) also reported that is more important to follow the decrease $\mathrm{AChE}$ activity in each worker through the years of occupational exposure, starting from the baseline level. The workers constantly exposed to pesticides with significantly reduced AChE activity at the time of testing, should be treated and transferred to other jobs. The main conclusion in the study of Lutovac et al. (2015) and also in numerous other studies related to occupational exposure to pesticides is that each pesticide should only be used by workers who are well versed in the way of its use, as well as the way of protecting them from poisoning.

\section{Conclusion}

In the present study, activities of several enzymes were examined in the serum of peach orchard workers with occupational exposure to carbamate and organophosphates pesticides, as well as the evaluation of physical signs and symptoms in exposed to pesticides workers was done.

The results have shown that there is statistically significant increased activity of ALP and CPK activity and significantly decreased AChE activity in orchard workers in comparison with these enzyme activities in healthy men without occupational exposure to pesticides. The weak negative correlation was detected between AChE activity and ALP activity, as well as between AChE activity and CPK activity. The results have shown that orchard workers with decreased serum AChE activity and increased serum CPK activity should be monitored as workers with greater risk for severe pesticide poisoning and sent to further investigations. These findings suggest that chronic occupational exposure to pesticides of lower toxicity, elicit mild toxic effects, as well as biochemical changes of unknown long-term consequences. 


\section{Disclosure of conflict of interest}

All authors declare that there are no real or apparent conflicts of interest that may have a bearing on the subject matter of the article.

\section{References}

Amer, M.M., Metwalli, M. and Abu El-Magd, Y., 2002. Skin diseases and enzymatic antioxidant activity among workers exposed to pesticides. Eastern Mediterranean Health Jounal 8, 1-9.

Araoud, M., Nerreti, F., Douki, W., Najjar, M.F., Kenani, A., 2010. Paraoxonase 1 correlates with butyrylcholinesterase and gamma glutamyl transferase in workers chronically exposed to pesticides. J. Occup. Health 32, 383-388. Available at: https://doi.org/10.1539/joh.o10017.

Araoud, M., Neffeti, F., Douki, W., Hfaiedh, H.B., Akrout, M., Hassine, M., Najjar, M.F., Kenani, A., 2012. Adverse effects of pesticides on biochemical and haematological parameters in Tunisian agriculture workers. Journal of Exposure Science and Environmental Epidemiology 22, 243-247. Available at: https://doi.org/10.1038/jes.2012.11.

Awad, O.M., El-Fiki, S.A., Abou-Shanab, R.A.I., Hassanin, N.M.A., Abd El Rahman, R., 2014. Influence of exposure to pesticides on liver enxymes and cholinesterase levels in male agriculture workers. Global NEST Journal 16(5), 1006-1015. Available at: https://doi.org/10.30955/gnj.001285.

Bhattacharyya, K., Phaujdar, S., Sarkar, R., Mullick, O.S., 2011. Serum creatine phosphokinase: A probable marker of severity in organophosphorus poisoning. Toxicol. Int. 18(2), 117-123. Available at: https://doi.org/10.4103/0971-6580.84263.

Burke, R.D., Todd, S.W., Lumsden, E., Mullins, R.J., Mamczarz, J., Fawcett, W.P., Gullapalli, R.P., Randall, W.R., Pereira, E.F.R., Albuquerque, E.X., 2017. Developmental neurotoxicity of the organophosphorus insecticide chloropyros: from clinical finding to preclinical models and potential mechanisms. Journal of Neurochemistry 142, 162-177. Available at: https://doi.org/10.1111/jnc.14077.

Burtis, C.A. and Ashwood E.R., 1994. Tietz Textbook of clinical chemistry, second ed. Elsevier Saunders, Philadelphia.

Burtis, C.A. and Ashwood E.R., 1999. Tietz Textbook of clinical chemistry, third ed. Elsevier Saunders, Philadelphia.

Chen, Y., 2012. Organophosphate-induced brain damage: Mechanisms, neuropsychiatric and neurological consequences, and potential therapeutic strategies. Neurotoxicol. 33, 391-400. Available at: https://doi.org/10.1016/j.neuro.2012.03.011.

Clark, R.F., 2006. Insecticides: Organic phosphorus compounds and carbamates. In: By: Flomenbaum, N.E., Goldfrank, L.R., Hoffman, R.S. et al (eds) Goldfrank's Toxicologic Emergencies, 8th Edn, McGraw-Hill, New York, chapter (109), pp: 1497-1513.

Cotton, J., Lewandowski, P., Brumby, S., 2015. Cholinesterase research outreach project (CROP): measuring cholinesterase activity and pesticide use in an agricultural community. BMC Public Health 15, 748-759. Available at: https://doi.org/10.1186/s12889-015-2076-8.

Dayanand, R. and Anikethana, G.V., 2012. Creatine kinase for prognostication in organophosphous poisoning. International Journal of Science and Research 3(11), 1336-1338.

Garcia-Garcia, C.R., Parron, T., Requena, M., Alarcon, R., Tsatsakis, A.M., Hernandez, A.F., 2016. Occupational pesticide exposure and adverse health effects at the clinical, hematological and biochemical level. Life Sciences 145, 274-283. Available at: https://doi.org/10.1016/j.lfs.2015.10.013.

Hernández, A.F., Gómez, M.A., Pérez, V., Garcia-Lario, J.V., Pena, G., Gil, F., Lopez, O., Rodrigo, L., Pino, G., Pla, A., 2006. Influence of exposure to pesticides on serum components and ezyme activities of cytotoxicity among intensive agriculture farmers. Environmental Research 102, 70-76. Available at: https://doi.org/10.1016/j.envres.2006.03.002.

Horrigan, L., Lawrence, R.S. and Walker, P., 2002. How sustainable agriculture can address the environmental and human health harms of industrial agriculture. Environ. Health. Perspect. 110, 445-456. Available at: https://doi.org/10.1289/ehp.02110445.

Jokanović, M., Maksimovic, M., 1997. Abnormal cholinesterase activity: understanding and interpretation. Eur. J. Cli. Chem. Clin. Biochem. 35(1), 11-16.

Kackar, R., Srivastava, M.K. and Raizada, R.B., 1999. Assessment of toxicological effects of mancozeb in male rats after chronic exposure. Indian J. Exp. Biol. 37, 553559.

Kopjar, N., Žunec, S, Mendaš, G., Micek, V., Kašuba, V., Mikolić, A., Milić, M., Pavičić, I., Čermak, A.M.M., Pizent, A., Lucić Vrdoljak, A., Želježić, D., 2018. Evaluation of chlorpyrifos toxicity through a 28-day study: Cholinesterase activity, oxidative stress responses, parent compound/metabolite levels, and primary DNA damage in blood and brain tissue of adult male Wistar rats. Chem. Biol. Interact. 279, 51-63. Available at: https://doi.org/10.1016/j.cbi.2017.10.029.

Lutovac, M., Popova, O.V., Jovanovic, Z., Berisa, H., Radoman, K., Ketin, S., Bojic, M., 2017. Management, Diagnostic and Prognostic Significance of Acetylcholinesterase as a Biomarker of the Toxic Effects of Pesticides in People Occupationally Exposed. Open Access Maced. J. Med. Sci. 5(7), 1021-1027. Available at: https://doi.org/10.3889/oamjms.2017.200.

McQueen, M.J., 1995. Clinical and analytical considerations in the utilization of cholinesterase measurements. Clin. Chim. Acta 237(1-2), 91-105.

Milić, M., 2018. Oxidative stress, cholinesterase activity, and DNA damage in the liver, whole blood, and plasma of Wistar rats following a 28-day exposure to glyphosate. Arh. Hig. Rada Toksikol. 69(2), 54-168. Available at: https://doi.org/10.2478/aiht-2018-69-3114.

Nermeen, A.M.H., and Abdelmonem, G.M., 2013. Correlation between serum creatine phosphokinase and severity of acute organophosphorus poisoning: A prospective clinical study (2012-2013). Journal of Environmental Science, Toxicology and Food technology 4(5), 18-29.

Neupane, D., Jors, E., Brandt, L., 2014. Pesticide use, 
erythrocyte acetylcholinesterase level and self-reported acute intoxication symptoms among vegetable farmers in Nepal: a cross-sectional study. Environ Health. 13, 98. Available at: https://doi.org/10.1186/1476-069X-13-98.

Panteghini, M., Bais, R and Solinge, W.W., 2006. Enzymes. In: Burtis, C.A., Ashwood, E.R. and Bruns, D.E. (Eds), Tietz Textbook of clinical chemistry and molecular diagnostics, fourth ed. Elsevier Saunders, Philadelphia, chapter 21, pp. 597-643.

Sukhdeep, K. and Dhanju, C.K., 2004. Enzymatic changes induced by some organophosphorus pesticides in female rats. Indian. J. Exp. Biol., 42, 1017-1019.

Szasz, G., 1976. Reaction-rate method for gammaglutamyltransferase activity in serum. Clin. Chem. 22(12), 2051-2055. Available at: https://doi.org/10.1093/clinchem/22.12.2051.

Szatkowska, B., Kwiatkowska, M., Michalowicz, J., 2012. Impact of chlorfenvinphos, an organophosphate insecticide on human blood mononuclear cells (in vitro). Pesti. Biochem. Physiol. 102, 175-181. Available at: https://doi.org/10.1016/j.pestbp.2012.01.001.

Tanen, D.A., 2007. Organophosphorus and carbamate insecticides. In: Olson, K.R. (ed.), Poisoning \& drug overdose. Lange medical books/McGraw-Hill, 5th Edn, New York, Chicago, Toronto, section II, pp. 291-295.

Tietz, N.W. et al., 1995. Clinical guide to laboratory tests, third ed. Elsevier Saunders, Philadelphia.

Trundle, D. and Marcial, G., 1988. Detection of cholinesterase inhibition. The significance of cholinesterase measurements. Ann. Clin. Lab. Sci. 18(5), 345-352.

Uzunhisarcikli, M. and Kalender, S., 2011. Protective effects of vitamins $\mathrm{C}$ and $\mathrm{E}$ against hepatoxicity induced by methyl parathion in rats. Ecotoxicol. Environmen. Safety 74, 21122118. Available at: https://doi.org/10.1016/j.ecoenv.2011.07.001.

Vassault, A., Grafmeyer, D., de Graeve, J., Cohen, R., Beaudonnet, A., Bienvenu, J., 1999. Quality specifications and allowable limits for validation of methods used in clinical biochemistry. Ann. Biol. Clin. 57(6), 685-695.

\title{
Резиме
}

\section{Ензимски промени кај работници во плантажа за овошје професионално изложени кон пестициди}

\author{
Светлана Цековска ${ }^{1}$, Сашо Столески², Виолета Солева ${ }^{3}$, \\ Катерина Тошеска-Трајковска ${ }^{1}$, Даница Лабудовиќ ${ }^{1}$, Јасна Богданска ${ }^{1}$, \\ Јулијана Брезовска-Кавракова ${ }^{1}$, Ирена Костовска ${ }^{1}$, Билјана Бауер ${ }^{4}$, \\ Соња Топузовска ${ }^{1}$
}

\author{
${ }^{1}$ Институт за медицинска и експериментална биохемија, Медицински факултет, \\ Универзитет ,,Св. Кирил и Методиј”, ул. 50-та Дивизија 6, 1000 Скопје, \\ Р. Македонија \\ ${ }^{2}$ Институт за трудова медицина, Скопје, Р. Македонија \\ ${ }^{3}$ Приватна здравствена институцчја Авицена лабораторија, \\ бул. Втора Македонска бригада 43, Скопје, Р. Македонија \\ ${ }^{4}$ Институт за фармакогнозија, Фармацевтски факултет, \\ Универзитет „Св. Кирил и Методиј”, ул. Мајка Тереза 47, 1000 Скопје, Р. Македонија
}

Клучни зборови: токсични ефекти, карбаматни пестициди, органофосфатни пестициди, серумски ензими, работници во овошна плантажа, професионална изложеност

Органофосфатите (OP) и карбаматите, често употребувани пестициди, може да предизвикаат мноштво штетни ефекти врз здравјето, кои се рангираат од едноставни надразнувања на кожата и очите до многу посериозни ефекти. Целта на оваа студија беше да се процени поврзаноста меѓу хроничната професионална изложеност и промените во серумските активности на аланин аминотрансферазата (ALT), аспартат аминотрансферазата (AST), гама глутамил тансферазата (GGT), алкалната фосфатаза (ALP), ацетил холинестеразата (AChE) и креатин фосфокиназата (СРК) кај работници од овошна плантажа. Во испитувањето беа вклучени 47 работници од овошна плантажа на праски, на возраст од 19 до 60 години, со месечна изложеност кон пестициди од 5 до 20 дена и 1 до 35 години работен стаж на плантажата. Контролната група ја сочинуваа 40 здрави, соодветни по возраст мажи, без професионална изложеност кон пестициди. Сите работници од плантажата се придржуваа кон мерките за 
безбедност. $68 \%$ од работниците изјавија дека имаат некои физички знаци и симптоми. Значително намалена активност на AChE беше утврдена кај 10,6\% од испитаниците, а зголемена активност на СРК кај 40,4\%. Детектирана е многу слаба негативна корелација меѓу AChE и активноста на ALP $(\mathrm{r}=-0,34, \mathrm{p}=0,001)$ и меѓу $\mathrm{AChE}$ и активноста на CPK $(\mathrm{r}=-0,25, \mathrm{p}=0,02)$. Не е утврдена корелација на серумската AChE со деновите на месечната експозиција, како и со годините на експозиција.

Резултатите покажаа дека работниците од овошната плантажа со намалена активност на $\mathrm{AChE}$ и зголемена активност на СРК треба да бидат следени како работници со поголем ризик за сериозно труење со пестициди. Овие наоди укажуваат дека хроничната професионална изложеност кон пестициди доведува до умерени токсични ефекти, како и до биохемиски промени со непознати долготрајни последици. 